\title{
Intravascular Myofibroblastic Proliferation
}

National Cancer Institute

\section{Source}

National Cancer Institute. Intravascular Myofibroblastic Proliferation. NCI Thesaurus.

Code C162591.

A morphologic finding indicating the proliferation of spindle-shaped myofibroblasts within vascular spaces in a tissue sample. 